\title{
Genetic relationship of lactation persistency with milk yield, somatic cell score, reproductive traits, and longevity in Slovak Holstein cattle
}

\author{
Eva Strapáková ${ }^{1}$, Juraj Candrák ${ }^{1}$, and Peter Strapák ${ }^{2}$ \\ ${ }^{1}$ Department of Genetics and Animal Breeding Biology, Slovak University of Agriculture in Nitra, \\ Tr. A. Hlinku 2, 94976 Nitra, Slovak Republic \\ ${ }^{2}$ Department of Animal Husbandry, Slovak University of Agriculture in Nitra, \\ Tr. A. Hlinku 2, 94976 Nitra, Slovak Republic \\ Correspondence to: Eva Strapáková (eva.strapakova@uniag.sk)
}

Received: 3 February 2016 - Revised: 30 June 2016 - Accepted: 6 July 2016 - Published: 14 July 2016

\begin{abstract}
The objective of this study was to estimate the breeding values (BVs) of lactation persistency, the test day of milk yield, the somatic cell score, reproductive traits (calving interval, days open), longevity in Slovak Holstein dairy cattle. BVs were used for the detection of relationships among the persistency of lactation and other selected traits. Data for the estimation of BVs of milk production and somatic cell score were collected from 855240 cows. BVs for reproductive traits were estimated for 352712 cows and for longevity for 528362 cows. The highest correlations were confirmed between the BV of persistency and the BV of test day milk yield at 100,200 , and 305 days $(-0.88,-0.65$, and -0.61$)$. Correlations between the BV of lactation persistency and the BV of somatic cell score at day 305 or the BV of somatic cell score persistency were favorable: -0.05 and -0.12 , respectively. The relationship between the BV of persistency and the BV of the calving interval or the $\mathrm{BV}$ of days open was 0.11 and 0.10 respectively. The selection for the persistency of lactation may not improve longevity because there is no relation between the BV of persistency and the BV of longevity $\left(r_{\mathrm{g}}=0.06\right)$.
\end{abstract}

\section{Introduction}

Breeding programs for the genetic improvement of dairy cattle should be built on four aspects: (1) increased income (higher production of milk/meat), (2) reduced costs (better fertility, fewer diseases, reduced culling rates), (3) ease of management (temperament, milking speed), and (4) advantages regarding to the sale of products (animal welfare, ethics, consumers concerns) (Bo, 2009).

For many years, milk production traits have held the leading position as important breeding goals. Research was accordingly concentrated on those factors in animal physiology and nutrition that would increase milk production at the peak of lactation rather than on the maintenance of milk secretion during the declining phase of lactation (Stefanon et al., 2002). In the period between calving and peak yield, incidences of most health problems, including mastitis, are high. At the beginning of lactation, cows are usually in a nega- tive energy balance; therefore, they need to mobilize body reserves to meet the increased nutrient demand for milk yield (Tamminga, 2000). Therefore, breeders try, amongst other measures, to reduce the costs of production by improving the persistency of lactation (Tekerli et al., 2000).

The persistency of lactation is defined as the ability to maintain a more or less constant yield during lactation. Thus, we can circumscribe this as a function of the flatness of the lactation curve. An animal is more persistent if the lactation curve has a flatter shape (Gengler, 1996).

High lactation persistency is associated with a slow rate of decline in production, whereas low persistency is associated with a rapid rate of decline (Dekkers et al., 1998). The persistency of lactation contributes to reducing the costs of the production system because there is an association with feeding and health costs, reproductive performance, resistance to disease, and the return from milk considering a 305-day pro- 
duction cycle (Dekkers et al., 1996). The effort to minimize the negative effect of selecting for milk yield on fertility and health traits may be helpful for considering the persistency of lactation (Sölkner and Fuchs, 1987).

Many countries use a diverse group of economically important traits (efficiency, health, fertility, and functional conformation) in the total merit index (TMI) to rank cattle for genetic selection. Recently, increasing attention has been focused on functional traits that are helpful for improving the management of dairy herds and for increasing the efficiency of breeding schemes. New functional traits are growing in importance because of recent declines in animal health and fitness (Egger-Danner et al., 2015). In recent years, there has been a stabilization or even an increase in genetic trends of functional traits (Miglior et al., 2012).

Relatively little research has been done to examine the genetic relationship between persistency in each lactation and other traits of importance in dairy cattle improvement. Information on the association among important traits such as fertility, longevity, persistency, and somatic cell score is lacking. Haile-Mariam et al. (2003) reported heritability and genetic and environmental correlations among the mean milk yield, persistency, the mean $\log _{e}$ somatic cell count (LnSCC), the slope of LnSCC, the calving interval, the length of lactation, and survival in Australian Holstein Friesian dairy cattle.

Muir et al. (2004) state that there is an association between a higher non-return rate at first service in first lactation and increased persistency. Higher 305 -day yields and greater persistency were associated with a longer calving interval.

Appuhamy (2006) found that primiparous and multiparous cows, which develop postpartum metabolic disorders (ketosis, milk fever, and displaced abomasuma) and periparturiant reproductive disorders (metritis, retained placenta, and ovarian cysts), tend to reach peak yield at later days in milk (DIM) and have flatter lactation curves for milk, fat, and protein yields. Conversely, mastitis after 100 DIM tends to produce less persistent lactations characterized by a faster rate of decline in milk, fat, and protein yields after peak production. Highest correlations between the different persistency traits and claw and leg diseases (from 0.13 to 0.46 ) were calculated by Harder et al. (2006). Muir et al. (2004) mention that heifers that had a difficult first calving or those that conceived successfully at first insemination in first lactation or had a longer interval between first and second calving tended to have more persistent first lactations $\left(r_{\mathrm{g}}=0.43,0.32\right.$ and 0.17). Authors estimated the strongest genetic correlation between a 305-day milk yield in the first lactation and the calving interval. This indicates that a longer calving interval is associated with a higher milk yield in the first lactation $(0.51 \pm 0.11)$.

The genetic correlations between persistency and reproductive traits were confirmed by Yamazaki et al. (2014a). Therefore, when seeking to increase milk yield or persistency, indicators of female fertility have to be included in the genetic evaluation to reduce undesirable side effects on fertility in cows.

\section{Persistency measures}

The most common mathematical model of persistency is based on Wood (1967). Other measures related to ratios between yields were defined by many authors. Sölkner and Fuchs (1987) defined persistency as the ratio between mean and peak yield. Johansson and Hansson (1940) introduced the ratio between partial yields; Ericson et al. (1988) expressed the same ratios as percentages. Other ratio methods share the same basic definitions of ratios between certain partial, peak, daily, total, or other yields (Gengler, 1996).

The procedures used nowadays to measure lactation persistency are based on the random regression test day model; the procedures have been extensively applied to the evaluation of milk production traits. The random regression test day model is the basis for the evaluation of persistency because the estimated breeding value for various parts of the lactation can be calculated (Jamrozik et al., 1997).

The objectives of this study were to estimate the breeding values (BVs) of lactation persistency, test day of milk yield, somatic cell score, reproductive traits (calving interval, days open), and longevity in Slovak Holstein dairy cattle and to analyze the relationship between the persistency of lactation and other selected traits.

\section{Material and methods}

\subsection{Estimation of breeding value for milk yield and somatic cell score}

Data for the estimation of breeding values of all aforementioned traits were obtained from the Slovak Holstein Association and from the results of dairy herd milk recording in the Slovak Republic performed by Slovak Breeding Services, S.E.

The genetic evaluation of the daily milk yield was performed for 12278 sires and 855240 cows. The pedigree file (minimum three generations) contained in total 2504397 animals.

The following single-trait random regression test day BLUP animal model was used to estimate breeding values.

$$
\begin{aligned}
y_{i j k l o} & =\mathrm{HTD}_{i l}+\sum_{m=1}^{5} a_{k l m} \mathrm{z}_{k l m}+\sum_{m} \\
& =1^{5} b_{j l m} z_{j l m}+p_{k l}+e_{i j k l o},
\end{aligned}
$$

where $y_{i j k l o}$ is daily milk $(\mathrm{kg})$; $\mathrm{HTD}_{i l}$ is the fixed effect of the herd test day; $a_{k l m}$ is the random animal effect (random regression coefficients); $b_{j l m}$ is the fixed effect of breeding type, age, and season (fixed regression coefficients) (four breeding type groups, three age groups, and two season 
groups); and $z_{j l m}$ is the coefficient-described lactation curve (Ali and Schaeffer, 1987) calculated as

$$
\begin{aligned}
z_{j l m} & =\left(1 c c^{2} \ln (1 / c)(\ln (1 / c))^{2}\right), \\
\text { with } c & =\text { lactation days } / 305,
\end{aligned}
$$

where $p_{k l}$ is the permanent random environmental effect and $e_{i j k l o}$ is the random residual effect.

Nowadays this model is used for the national genetic evaluation system of production traits and somatic cell score.

The random regression test day BLUP animal model is based on the estimation of the breeding value of lactation persistency (BV_per). A formula described by Jamrozik et al. (2001) was used:

BV_per $=110 \times\left(b_{280}-b_{60}\right)$,

where BV_per is the breeding value of lactation persistency, $\mathrm{bv}_{280}$ is the breeding value of milk yield on the 280th day in milk (DIM), and bv 60 is the breeding value of milk yield on the 60th DIM.

The same models (test day of milk yields and persistency of lactation) were used for the estimation of BV for somatic cells. In order to maintain a normal distribution of data, the somatic cell count (SCC) was transformed to somatic cell score (SCS) as follows:

$\mathrm{SCS}=\log 2(\mathrm{SCC} / 100)+3$,

where SCC is the somatic cell count per milliliter.

For the milk yields and somatic cell score the genetic parameters from the national genetic evaluation system were applied ( $h^{2}$ for milk yields is 0.309 , and $h^{2}$ for somatic cell score is 0.212 ).

\subsection{Estimation of breeding value for reproductive traits}

The data for a genetic evaluation of reproductive traits consisted of 756512 records of 352712 Holstein cows until the fifth lactation. Evaluated cows were born during the years 1989-2007. The pedigree file involved 522280 records until the fifth generation.

Evaluated reproductive traits involved calving interval and days open. These traits were analyzed separately in a singletrait animal model as described by Riecka (2011):

$$
\begin{aligned}
Y_{i j k l m}^{1,2}= & \mathrm{HYS}_{i}+L_{j}+\mathrm{BT}_{k}+\mathrm{AG}_{l}+b(\operatorname{dim})_{i j k l m} \\
& +c(\text { milk })_{i j k l m}+a_{m}+e_{i j k l m},
\end{aligned}
$$

where $Y_{i j k l m}^{1,2}$ is the calving interval (days open); $\mathrm{HYS}_{i}$ is the fixed effect of the herd, year, and season of calving; $L_{j}$ is the fixed effect of parity; $\mathrm{BT}_{k}$ is the fixed effect of the breed type (four breed type groups according to Holstein genes); $\mathrm{AG}_{l}$ is the fixed effect of the age at calving; $b(\mathrm{dim})_{i j k l m}$ is the fixed effect of the days in milk; $c(\text { milk })_{i j k l m}$ is the fixed effect of the milk yield; $a_{m}$ is the random effect of the animal; and $e_{i j k l m}$ is the residuum (random effect).

Estimated BVs were expressed as the relative breeding values (RBVs):

$\mathrm{RBV}=100-\frac{(\mathrm{BV})}{\mathrm{SD}} \times 12$,

where BV is the breeding value (negative is favorable) and $\mathrm{SD}$ is the breeding value standard deviation of bulls in the genetic reference base.

The heritability for calving interval was 0.027 and for days open 0.022 (Riecka, 2011).

The data were performed using the program SAS 9.2 (SAS Institute Inc., Cary, NC, USA, 2008) Enterprise Guide 4.2. The Misztal et al. (2002) program package (BLUPF90) was used for the estimation of breeding values for milk yield, somatic cell score, and reproductive traits. BLUPF90 is a mixed model of programs, which supports general multipletrait models with missing values and different models and traits, and random regressions.

\subsection{Estimation of breeding value for longevity}

The file of longevity data consisted of 1307177 records on the milk yield from the first until the fifth lactation and the productive life of 528362 cows with birth years between 1995 and 2011. The length of productive life was calculated as the number of days from the first calving until culling or censoring. Animals with an unknown sire and culling day, with more than five lactations, and those sold for other purpose were considered as censored records.

The software Survival Kit v6.0 (Ducrocq et al., 2010) was used to estimate the breeding values for the length of functional productive life. The survival was analyzed using a Weibull proportional hazard sire model:

$\lambda(t)=\lambda 0(t) \exp (\mathrm{pl}+m+\mathrm{hs}+$ age + hys $+s)$,

where $\lambda(t)$ is the hazard function (instantaneous probability of culling) for a given cow at time $t ; \lambda 0(t)$ is the Weibull baseline hazard function; $\mathrm{pl}$ is the fixed time-dependent effect of the parity $(n=5) ; m$ is the fixed time-dependent effect of the milk production class, expressed as a standard deviation (SD) from the average within the herd year (six classes); hs is the fixed time-dependent effect of the variation of herd size expressed as an increase $(+)$ or decrease $(-)$ in the number of cows in comparison with the previous year (six classes); age is the fixed time-independent effect of the age at first calving (five classes); hys is the random timedependent effect of the herd $\times$ year $\times$ season interaction, following a log-gamma distribution $(n=23618)$; and $s$ is the time-independent random effect of the sire of the cow, assumed to follow a multivariate normal distribution.

Pedigree included 4799 sires and the total bull number in the pedigree was 7118 . 
Table 1. Descriptive statistics for BV of lactation persistency and $\mathrm{BV}$ of test day milk production $(\mathrm{kg})$.

\begin{tabular}{lcrrrc}
\hline Trait & $N$ & Mean & SD & Minimum & Maximum \\
\hline BV_100 & 13063 & -74.699 & 229.636 & -742.3 & 1147 \\
BV_200 & 13063 & -73.963 & 241.605 & -1059 & 1380 \\
BV_300 & 13063 & -47.733 & 162.093 & -1007 & 1120 \\
BV_305 & 13063 & -196.392 & 569.097 & -2663 & 3354 \\
BV_per & 13063 & 54.735 & 345.470 & -1934 & 1249 \\
\hline
\end{tabular}

SD: standard deviation; BV_100 $(200,300,305)$ days: breeding values for cumulated milk production; BV_per: breeding value of lactation persistency.

The breeding value for functional productive life was expressed as a relative breeding value, with an average of 100 and a genetic standard deviation of 12 .

$\mathrm{RBV}_{\text {long }}=((\mathrm{eval}-a) / b) \times c+d$,

where $\mathrm{RBV}_{\text {long }}$ is the sire's relative breeding value of longevity, "eval" estimates the regression coefficient (sire's breeding value), $a$ is the mean of the base adjustment, $b$ is the standard deviation of the base, $c$ is the standard deviation of expression (including sign if the scale is reversed), and $d$ is the base of expression.

Heritability on the original scale was 0.13 (Strapáková, 2012). The statistical software SAS 9.2 and the application Enterprise Guide 4.2 (SAS, 2008) were used for the preparation of the databases. Correlations between BV_per and BVs vs. other traits were calculated using the PROC CORR procedure (SAS, 2008).

\section{Results and discussion}

\subsection{Persistency of lactation and milk yield}

In this study, the BVs of 13063 Holstein sires were compared. The descriptive statistics for BVs of lactation persistency and milk yield are given in Table 1. Average BVs for milk yield at 100, 200, 300, and 305 days were negative. This is likely to be caused by a large number of bulls with few daughters.

$\mathrm{BV}$ for lactation persistency was positive, but the breeding value at the 280th lactation days can be higher compared to $\mathrm{BV}$ at the 60th day. The genetic evaluation for the specific day is not the same as phenotypic values (milk production). The evaluation of persistency is strongly influenced by the preselection of animals according to milk yields. The use of bulls with high breeding values of persistency is unusual, though the number of these bulls is high. In breeding, bulls with high breeding values for milk yields are more preferred. Jamrozik et al. (1997) claim that a good measure of persistency should be independent of lactation milk yield.

One of the characteristics of the lactation persistency is the correlation with milk yield. In this study, correlations between the BV of persistency and the BV of cumulated milk production for 100,200 , and 305 days were $-0.88,-0.65$,
Table 2. Correlations between BV of lactation persistency and BV of test day milk production.

\begin{tabular}{|c|c|c|c|c|c|}
\hline & BV_100 & BV_200 & BV_300 & BV_305 & BV_per \\
\hline BV_100 & 1 & $\begin{array}{r}0.917 \\
<0.0001\end{array}$ & $\begin{array}{r}0.401 \\
<0.0001\end{array}$ & $\begin{array}{r}0.907 \\
<0.0001\end{array}$ & $\begin{array}{r}-0.881 \\
<0.0001\end{array}$ \\
\hline BV_200 & & $\begin{array}{r}1 \\
<0.0001\end{array}$ & $\begin{array}{r}0.699 \\
<0.0001\end{array}$ & $\begin{array}{r}0.994 \\
<0.0001\end{array}$ & -0.658 \\
\hline BV_300 & & & $\begin{array}{r}1 \\
<0.0001\end{array}$ & $\begin{array}{r}0.743 \\
<0.0001\end{array}$ & 0.067 \\
\hline BV_305 & & & & $\begin{array}{r}1 \\
<0.0001\end{array}$ & -0.615 \\
\hline BV_per & & & & & 1 \\
\hline
\end{tabular}

Table 3. Descriptive statistics for BV of lactation persistency and $\mathrm{BV}$ s of somatic cell score.

\begin{tabular}{lccrrr}
\hline Trait & $N$ & Mean & SD & Minimum & Maximum \\
BV_per_scs & 12652 & 0.508 & 37.567 & -185.190 & 191.950 \\
BV_scs_305 & 12652 & 3.978 & 78.452 & -348.550 & 435.880
\end{tabular}

BV_per_scs: breeding value of somatic cell score persistency; BV_scs_305: breeding value of somatic cell score in 305 days.

and -0.61 (Table 2). Between BV_300 and BV_per, a correlation (0.06773) was not found as the last period of the lactation does not influence the persistency. The formulation of persistency better describes the start of lactation.

Estimated correlations were similar in sign but different in magnitude compared to the results of Cobuci et al. (2007), who reported lower genetic correlations for persistency with a 305-day milk yield $(-0.45)$, similar to Kheirabadi and Alijani (2014) $(-0.33)$ and Otwinowska-Mindur and Ptak (2015) (-0.55). Hickson et al. (2006) reported negative correlations of peak milk yields with three measures of lactation persistency $(-0.29,-0.39$, and -0.78$)$.

On the contrary, Yamazaki et al. (2014a) found positive genetic correlations over the first three lactations $(0.48,0.41$, and 0.41). The relationship between 305-day milk yield and persistency was confirmed also by Cobuci et al. (2007) and Boujenane and Hilal (2012), with values of $r_{\mathrm{g}}=0.49$ and $r_{\mathrm{g}}=0.89$, respectively.

\subsection{Persistence and somatic cell score}

The genetic relationship between lactation curve traits and the somatic cell count is of great interest for dairy cattle breeding. Simple statistics of the BV of lactation persistency (BV_per) and BVs of somatic cell score are given in Table 3. They are evaluated for 12652 Holstein bulls.

The correlations between BV_per and the BV of somatic cell score (BV_scs_305) and the BV of somatic cell score persistency (BV_per_scs) were favorable, i.e. negative (Table 4). Negative correlation between lactation persistency and SCS persistency $(-0.123)$ indicates an improvement in the persistency of lactation, with a moderate decrease in SCS. 
Table 4. Correlations between $\mathrm{BV}$ of lactation persistency and $\mathrm{BVs}$ of somatic cell score.

\begin{tabular}{lrrr}
\hline & BV_per & BV_per_scs & BV_scs_305 \\
\hline BV_per & 1 & -0.123 & -0.059 \\
& & $<0.0001$ & $<0.0001$ \\
BV_per_scs & & 1 & 0.036 \\
BV_scs_305 & & $<0.0001$ \\
\end{tabular}

Table 5. Descriptive statistics for RBVs of reproduction traits and $\mathrm{BV}$ of lactation persistency.

\begin{tabular}{lcrrrr}
\hline Trait & $N$ & Mean & SD & Minimum & Maximum \\
\hline BV_per & 1296 & -267.569 & 302.634 & -1344 & 750.700 \\
RBV_do & 1296 & 99.995 & 11.641 & 43.142 & 156.059 \\
RBV_ci & 1296 & 99.943 & 11.639 & 47.473 & 143.320 \\
\hline
\end{tabular}

RBV_do: relative breeding value of days open; $R B V$ _ci: relative breeding value of calving interval.

Vicario et al. (2007) state that genetic improvement of lactation persistency results in a reduction in SCS $\left(r_{\mathrm{g}}=-0.55\right)$ that is simultaneous with persistency of lactation. The negative average genetic correlation between daily SCS and a persistency of -0.23 and -0.22 in the first and second lactations was described by Yamazaki et al. (2013). Cole and Null (2008) found a genetic correlation of persistency with SCS yield that ranged from -0.17 to -0.42 and a correlation of persistency for milk with persistency of SCS that ranged from -0.37 to -0.52 for five cattle breeds. A negative correlation was confirmed also by Haile-Mariam et al. (2003) $(-0.29)$. It follows that cows with a high cell count have a reduced persistency of milk yield.

\subsection{Persistency of lactation and reproductive traits}

Reproduction is an important factor in determining the efficiency of animal production. Poor reproductive performance leads to economic losses due to reduced production, a prolonged calving interval, and additional costs. In this study the relationship of the RBV of the calving interval and days open with the BV of persistency of lactation of 1296 Holstein sires (Tables 5,6 ) was analyzed.

The correlation between persistency and calving interval was 0.112, which is in accordance with Muir et al. (2004) $\left(r_{\mathrm{g}}=0.17\right)$. Haile-Mariam et al. (2003) found a correlation close to $0(-0.02)$, whereas Muir and Schaeffer (2003) reported positive and moderate correlations ( 0.34 on the first and 0.40 on the second lactation). Thus, the longer interval from the first to second calving corresponds to the higher persistency in the first two lactations. The longer calving intervals can be viewed as undesirable; therefore, genetically an antagonistic relationship exists between persistency and reproductive performance.
Table 6. Correlations between RBVs of reproductive traits and BV of lactation persistency.

\begin{tabular}{lrrr}
\hline & BV_per & RBV_do & RBV_ci \\
\hline BV_per & 1 & 0.103 & 0.112 \\
& & 0.0002 & $<0.0001$ \\
RBV_do & & 1 & 0.942 \\
& & & $<0.0001$ \\
RBV_ci & & & 1 \\
\hline
\end{tabular}

Table 7. Descriptive statistics for relative breeding value of longevity and $\mathrm{BV}$ of lactation persistency.

\begin{tabular}{lcrrrr}
\hline Trait & $N$ & Mean & SD & Minimum & Maximum \\
\hline RBV_long & 1585 & 100.348 & 12.528 & 61.934 & 162.108 \\
BV_per & 1585 & -202.332 & 332.804 & -1328 & 799.900 \\
\hline RBV_long: relative breeding value of longevity.
\end{tabular}

Lean et al. (1989) state that increasing lactation persistency does not improve the conception rates. They declared that cows with higher than average peak milk yields were less likely to conceive with one or two services.

The correlation coefficient between the BV of persistency and the RBV of days open (0.103) (Table 6) was in accordance with a study of Yamazaki et al. (2014b) and Muir and Schaeffer (2003).

Table 8. Correlations between BV of persistency and RBV of longevity.

\begin{tabular}{lrr}
\hline & RBV_long & BV_per \\
\hline RBV_long & 1 & 0.066 \\
BV_per & & 0.008 \\
& & 1 \\
\hline
\end{tabular}

\subsection{Persistency of lactation and longevity}

For many years the genetic improvement of dairy cattle was based almost exclusively on increased production per cow. However, many functional traits have negative genetic correlations with milk yield, and a reduction in genetic merit for health and fitness was detected. Herd management has faced with the challenge of compensating for these effects and of balancing fertility, udder health, and metabolic diseases with increased production to maximize profit without compromising welfare (Egger-Danner et al., 2015).

The length of productive life is probably the most important trait in cattle breeding. The longer animals remain productive in a herd, the fewer replacements are needed. The $\mathrm{RBV}$ of longevity and the BV of lactation persistency were estimated for 1585 Holstein bulls. Descriptive statistics are given in Table 7. 
The correlation between the BV of persistency and the RBV of longevity was 0.06 (Table 8), which is in accordance with Haile-Mariam et al. (2003), who found that genetic correlations near 0 (0.04). Murray (2011) confirmed the relationship of herd life with a high persistency of lactation $(-0.11)$, i.e. high scores for lactation persistency are actually associated with a shorter herd life.

\section{Conclusions}

The advantages of increasing persistency in dairy cattle are indisputable on the practical herd level. More persistent lactation brings longer high-production periods. An important characteristic of the persistency measure is its correlation with the 305-day milk yield. The results of this study show that the genetic correlation between both abovementioned traits was -0.61 ; therefore, cows with a high genetic level for persistency would tend to have a lower genetic level for milk production. The genetic relationships among reproductive traits and persistency were low (moderate positive influence of reproduction on persistency). Correlations of the $\mathrm{BV}$ of somatic cell score with the BV of lactation persistency were slightly favorable, i.e. negative. A high somatic cell count can negatively affect the persistency of milk yield to a certain extent. The correlation of lactation persistency with the RBV of longevity was close to 0 , meaning that there is no significant relationship.

Acknowledgements. Financial support was provided by the projects KEGA No.035SPU-4/2015 and VEGA 1/0724/16.

Edited by: S. Maak

Reviewed by: two anonymous referees

\section{References}

Ali, T. E. and Schaeffer, L. R.: Accounting for covariances among test day milk yields in dairy cows, Canadian J. Anim. Sci., 67, 637-644, 1987.

Appuhamy, R.: Phenotypic Relationships between Lactation persistency and Common Health Disorders in Dairy Cows, Diploma thesis, Blacksburg, VA, 94 pp., 2006.

Bo, N.: Practical cattle breeding in the future - commercialized or co-operative, across borderlines between countries and organizations, available at: https://journal.interbull.org/index.php/ib/ article/viewFile/1122/1113 (last access: 26 May 2015), 2009.

Boujenane, I. and Hilal, B.: Genetic and non genetic effects for lactation curve traits in Holstein-Friesian cows, Archiv Tierzucht, 55, 450-457, 2012.

Cobuci, J. A., Euclydes, R. F., Costa, C. N., De Almeida Torres, R., Lopes, P. S., and Pereira, C. S.: Genetic evaluation for persistency of lactation in Holstein cows using a random regression model, Genet. Mol. Biol., 30, 349-355, 2007.

Cole, J. B. and Null, D. J.: Genetic evaluation of lactation persistency for five breeds of dairy cattle, J. Dairy Sci., 92, 2248-2258, 2008.
Dekkers, J. C. M., Jamrozik, J., Ten Hag, J. H., Schaeffer, L. R., and Weersink A.: Genetic and economic evaluation of persistency in dairy cattle, Interbull Bulletin, 12, 97-102, 1996.

Dekkers, J. C. M., Ten Haag, J. H., and Weersink, A.: Economic aspects of persistency in dairy cattle, Livest. Production Sci., 53, 237-252, 1998.

Ducrocq, V., Sölkner, J., and Mészáros, G.: The Survival Kit v6.0, User's manual, 68 pp., 2010.

Egger-Danner, C., Cole, J. B., Pryce, J. E., Gengler, N., Heringstad, B., Bradley, A., and Stock, K. F.: Invited review: overview of new traits and phenotyping strategies in dairy cattle with a focus on functional traits, Animal, 9, 191-207, 2015.

Ericson, K., Danell, B., and Rendel, J.: Crossbreeding effects between two Swedish dairy breeds for production traits, Livest. Prod. Sci., 20, 175-192, 1988.

Gengler, N.: Persistency of lactation yields: A review, Interbull Bulletin 12, 87-96, 1996.

Haile-Mariam, M., Bowman, P. J., and Goddard, M. E.: Genetic and environmental relationship among calving interval, survival, persistency of milk yield and somatic cell count in dairy cattle, Livest. Prod. Science, 80, 189-200, 2003.

Harder, B., Bennewitz, J., Hinrichs, D., and Kalm, E.: Genetic parameters for health traits and their relationship to different persistency traits in German Holstein dairy cattle, J. Dairy Sci, 89, 3202-3212, 2006

Hickson, R. E., Lopez-Villalobos, N., Dalley, D. E., Clark, D. A., and Holmes, C. W.: Yields and Persistency of Lactation in Friesian and Jersey Cows Milked Once Daily, J. Dairy Sci., 89, 2017-2024, 2006.

Jamrozik, J., Schaeffe, L. R., and Dekkers, J. C. M.: Genetic evaluation of dairy cattle using test day yields and random regression model, J. Dairy Sci., 80, 1217-1226, 1997.

Jamrozik, J., Schaeffe, L. R., and Weigel, K. A.: International Genetic Evaluation of Dairy Sires and Cows Using First Lactation Test Day Yields, Interbull Open Meeting, Budapest, Hungary, 2001.

Johansson, I. and Hansson, A.: Causes of variation in milk and butterfat yield in dairy cows, Kungl. Landtbr. Akab. Tidskr., 79, 1$127,1940$.

Kheirabadi, K. and Alijani, S.: Genetic parameters for milk production and persistency in the Iranian Holstein population by the multitrait random regression model, Archiv Tierzucht, 57, 1-12, 2014.

Lean, I. J., Gallard, J. C., and Scott. J. L.: Relationships between fertility, peak milk yields and lactational persistency in dairy cows, Theriogenology, 31, 1093-1103, 1989.

Miglior, F., Chesnais, J., and Van Doormal, B. J.: Genetic improvement a major component of increased dairy farm profitability, available at: http://www.icar.org/cork_2012/Manuscripts/ Published/MigliorA1.pdf (last access: 27 May 2015), 2012.

Misztal, I., Tsuruta, S., Strabel, T., Auvray, B., Druet, T., and Lee, D. H.: BLUPF90 and related programs (BGF90), 7th World Congress on Genetics Applied to Livestock Production, Montpellier, France, 19-23 August, 2002.

Muir, B. L. and Schaeffer, L. R.: Relationship Between Persistency and Reproductive Performance in the First Two Lactations of Ontario Holsteins, Technical Committee of the Canadian Genetic Evaluation Board, Guelph, Canada, 19 March, 2003. 
Muir, B. L., Fatehi, J., and Schaeffer, L. R.: Genetic Relationships Between Persistency and Reproductive Performance in FirstLactation Canadian Holsteins, J. Dairy Sci., 87, 3029-3037, 2004.

Murray, B.: Finding the Tools to Achieve Longevity in our Dairy Cows, 28th Annual South Western Ontario Dairy Symposium, Woodstock, Canada, 24 February, 2011.

Otwinowska-Mindur, A. and Ptak, E.: Genetic analysis of persistency in the Polish Holstein-Friesian cows, Animal Sci. Papers and Reports, 33, 109-117, 2015.

Riecka, Z.: Genetic Evaluation of Fertility Traits in Holstein Cattle in The Slovak Republic, Dissertation, Nitra: SPU, 108 pp., 2011.

SAS ${ }^{\circledR} 9.2$ Enhanced Logging Facilities, SAS Institute Inc., Cary, NC, USA, 2008.

Sölkner, J. and Fuchs, W.: A comparison of different measures off persistency with special respect to variation of test-day milk yields, Livest. Prod. Sci., 16, 305-319, 1987.

Stefanon, B., Colitti, M., Gabai, G., Knight, Ch. H., and Wilde, C. J.: Mammary apoptosis and lactation persistency in dairy animals, J. Dairy Research, 69, 37-52, 2002.

Strapáková, E.: Genetic and breeding analysis of longevity in cattle, Dissertation, Nitra: SUA, 144 pp., 2012.

Tamminga, S.: Issues arising from genetic change: ruminants, in: The challenge of Genetic Change in Animal Production, edited by: Hill, W. G., Bishop, S. C., McGuirk, B., McKay, J. C., Simm, G., and Webb, A. J., British Society of Animal Science, Occasional publication no. 27, 55-62, 2000.
Tekerli, M., Akinci, Z., Dogan, I., and Akcan, A.: Factors affecting the shape of lactation curves of Holstein cows from the Balikesir Province of Turkey, J. Dairy Sci., 83, 1381-1386, 2000.

Vicario, D., Steri, R., Cappio Borlino, A., and Macciotta, N. P. P.: Analysis of genetic correlations between multivariate measures of lactation persistency and somatic cell score in Italian Simmental Cattle, Ital. J. Anim. Sci., 6, p. 224, 2007.

Yamazaki, T., Hagiya, K., Takeda, H., Sasaki, O., Yamaguchi, S., Sogabe, M., Saito, Y., Nakagawa, S., Togashi, K., Suzuki, K., and Nagamine, Y.: Genetic correlations between milk production traits and somatic cell scores on test day within and across first and second lactations in Holstein cows, Livest. Sci., 152, 120 126, 2013.

Yamazaki, T. A. N., Hagiya, K. A., Takeda, H. B., Yamaguchi, S. C., Osawa, T. D., and Nagamine, Y. E.: Genetic correlations among female fertility, 305-day milk yield and persistency during the first three lactations of Japanese Holstein cows, Livest. Sci., 168, 26-31, 2014a.

Yamazaki, T. A. N., Hagyia, H., Yamaguchi, S. C., Osawa, T. D., and Nagamine, Y. E.: Genetic Analysis of Reproductive Traits, Milk Yield, and Persistency during the First 3 lactations, 10th World Congress on Genetics Applied to Livestock Production, Vancouer, Canada, 17-22 August, 2014b.

Wood, P. D. P.: Algebraic model of the lactation curve in cattle, Nature, 216, 164-165, 1967. 